\title{
Storage tolerance of five short-day onion cultivars during a 12-week period'
}

\author{
Guillermo J. Fornaris, ${ }^{2}$ Elvin Caraballo, ${ }^{2}$ Rubén Guadalupe, ${ }^{s}$ \\ and Evangelina Recio de Hernández
}

\begin{abstract}
The number of damaged bulbs of five short-day onion (Allium cepa L.) cultivars was determined during 12 weeks in storage at an average mean room temperature of $27.4^{\circ} \mathrm{C}$ and approximately $80 \%$ relative humidity. Percentage of total solids before storage ranged from $6.84 \%$ to $8.06 \%$ at the beginning of the study. Bulbs with symptoms of bacterial soft rot (Erwinia carotovora), black mold rot (Aspergillus niger) or sprouted were recorded and discarded weekly. At the end of the 12-week storage period, bacterial soft rot was the most damaging condition, followed by black mold rot. The cumulative percentage of total bulbs discarded was greater in the deep, flat shaped Granex 33 cultivar (16.14\%). This percentage was significantly higher than that for bulbs discarded among cultivars Texas Grano 502 (6.16\%), Granex 429 (3.89\%), Texas Grano $1025 Y(3.13 \%)$, and Ringer Grano $(2.44 \%)$. There were no significant differences among these four cultivars.
\end{abstract}

\section{RESUMEN}

Tolerancia de cinco cultivares de cebolla de días cortos al almacenamiento por 12 semanas

Se contaron los bulbos defectuosos de cinco cultivares de cebolla (Allium cepa $\mathrm{L}$.) de días cortos durante 12 semanas almacenados a una temperatura media ambiente de $27.4^{\circ} \mathrm{C}$ y una humedad relativa de aproximadamente $80 \%$. Al comenzar el estudio, el porcentaje de sólidos totales fluctuó de $6.84 \%$ a $8.06 \%$. Se contaron y se descartaron semanalmente bulbos con síntomas de pudrición blanda (Erwinia carotovora) y moho negro (Aspergillus niger), y los germinados. A las 12 semanas la pudrición blanda fue la condición más dañina, seguida por el moho negro. El porcentaje acumulativo más alto del total de bulbos descartados $(16.14 \%)$ correspondió a la cultivar Granex 33, de forma bien achatada. Este fue significativamente mayor al de las cultivares Texas Grano $502(6.16 \%)$, Granex $429(3.89 \%)$, Texas Grano 1025 Y (3.13\%) y Ringer Grano $(2.44 \%)$. No hubo diferencias significativas entre estas cuatro cultivares.

\section{INTRODUCTYON}

During fiscal years 1984-85 and 1985-86 per capita consumption of onion (Allium cepa L.) ranked second among all fresh vegetable crops in Puerto Rico, with an average for the 2 years of $6.38 \mathrm{~kg}$ per capita (7).

\footnotetext{
${ }^{1}$ Manuscript submitted to Editorial Board 15 December 1989.

${ }^{2}$ Assistant Researcher, Department of Horticulture.

${ }^{3}$ Horticulturist, Department of Horticulture.

${ }^{4}$ Assistant Food Technologist, Laboratory of Food Technology.
} 
In spite of the great year-round demand for onions, most of the limited local production is obtained from January to May. The mild short-day onions produced in Puerto Rico cannot be stored too long. Therefore, they are usually marketed and consumed soon after harvest. These factors, among others, limit the marketing period for locally grown onions.

According to the U. S. Department of Agriculture, Bermuda type onions, which belong to the short-day onion group, can usually be stored at $0^{\circ} \mathrm{C}$ and 65 to $70 \%$ relative humidity (6). A recent evaluation of onion bulbs of the Granex short-day cultivar grown in Georgia, U. S., showed a dramatic increase in shelf-life under controlled atmosphere storage (12). At present, onion storage at low temperature or under controlled atmosphere does not seem to be economically feasible in Puerto Rico.

The storage life of onions depends on many factors, but the most important is the cultivar per se (11). Differences among short-day onion cultivars have been reported in Florida (5) and Texas (9), and new releases are showing improved storage quality $(9,10)$. This paper reports on the postharvest evaluation of five short-day onion cultivars during a 12 -week storage period.

\section{MATERIALS AND METHODS}

On 10 December 1986, cultivars Texas Grano 502, Granex 33, Texas Grano 1025Y, Granex 429 and Ringer Grano were direct-seeded into four field plots per cultivar in a randomized complete block design. Each plot consisted of two beds $93 \mathrm{~cm}$ wide and $366 \mathrm{~cm}$ long, with two rows of plants per bed $31 \mathrm{~cm}$ apart. After thinning, plants were spaced at $8 \mathrm{~cm}$ apart within rows. This work was conducted at the Fortuna Agricultural Experiment Substation, located on the semiarid southern coast of Puerto Rico. The soil is a Mollisol of the San Antón series (Cumulic Haplustolls, fine loamy, mixed, isohyperthermic) on nearly level alluvial fans (3).

All cultivars were grown according to cultural practices recommended for onions in Puerto Rico (2). In addition to the recommended application of Dachtal W-75 as a preemergent herbicide immediately after planting, Fusilade and Goal were used as postemergent herbicides 6 weeks later. Diazinon AG-500 was the only insecticide occasionally used; no fungicide was applied.

Bulbs of Granex 33 and Ringer Grano were harvested 3 April; Granex 429 and Texas Grano 1025Y, 20 April; and Texas Grano 502, 23 April 1987. We cured bulbs in a well-ventilated greenhouse for 4 days, before pruning tops and roots. Three days later, 130 marketable bulbs per cultivar were sent to the Food Technology Laboratory in Río Piedras. All

"Trade names are used in this publication solely for the purpose of providing specific information. Mention of trade names does not constitute a guarantee, warranty or endorsement by the Agricultural Experiment Station indicating superiority to the other similar products not mentioned. 
were classified by size. A sample of eight bulbs per cultivar was used to determine percentage of total solids by drying for 20 to 24 hours in a force draft oven at $60^{\circ}$ to $80^{\circ} \mathrm{C}$. After sizing, four samples per cultivar consisting of 27 bulbs each, were stored for 12 weeks in perforated plastic crates and placed on four shelves (complete blocks) at an average mean room temperature of $27.4^{\circ} \mathrm{C}$, with approximately $80 \%$ relative humidity. Pike (8) recommends that short-day onions be stored for evaluation under warm, humid conditions because a high percentage of the short-day onions are produced in hot humid areas.

During the 12-week storage period the bulbs were evaluated weekly. Sprouting and decay symptoms were recorded, and the damaged bulbs were removed immediately. Because the bulbs were individually evaluated, contamination from bulbs showing decay symptoms was reduced.

\section{RESULTS AND DISCUSSION}

Table 1 presents seed source and cultivar characteristics such as seed type, bulb shape and skin color. In addition, it includes yield data in kilogram per hectare. Significantly higher yields were obtained from Granex $429(34,666 \mathrm{~kg} / \mathrm{ha})$ and Texas Grano $1025 \mathrm{Y}(33,880 \mathrm{~kg} / \mathrm{ha})$. Ringer Grano was the lowest yielder, with only $19,108 \mathrm{~kg} / \mathrm{ha}$. This yield value was significantly lower than those from all other cultivars. As for seed type, the only two hybrids are Granex 33 and Granex 429. Bulbs ranged from near globular to top shaped, except for Granex 33, whose bulbs were deep and flat. Voss et al. mention that the one generalization that can be made on the classification by bulb shape is that only globe-shaped cultivars can be stored for any length of time; however, not all globeshaped cultivars can be stored (13). The skin of all cultivars under evaluation was yellow to straw-yellow. No field damage attributable to insects and diseases was observed.

TABLE 1.-Cultivar characteristics and estimated yield in 1986-87 planting at Fortuna Agricultural Experiment Substation

\begin{tabular}{lllllc}
\hline Cultivar & Seed type & Bulb shape & Skin color & Seed source $^{2}$ & Estimated yield $^{-}$ \\
\hline Granex 429 & Hybrid & Near globe & Yellow & Asgrow & $34,666 \mathrm{a}^{\prime}$ \\
Texas Grano 1025Y & O.p. & Tall globe & Straw-yellow & Asgrow & $33,880 \mathrm{a}$ \\
Texas Grano 502 & O.p. & Top shaped & Straw-yellow & Asgrow & $26,603 \mathrm{~b}$ \\
Granex 33 & Hybrid & Deep, flat & Yellow & Asgrow & $26,061 \mathrm{~b}$ \\
Ringer Grano & O.p. & Top shaped & Yellow & Sunseeds & $19,108 \mathrm{c}$ \\
\hline
\end{tabular}

O.p. = open pollinated.

${ }^{2}$ Seed companies which supplied the seeds used in this trial.

${ }^{3}$ Estimated yield, in kilogram per hectare.

"Values in columns followed by the same letter do not differ statistically $(P=0.05)$ according to Duncan's multiple range test. 
All cultivars except Ringer Grano were previously evaluated in the 1985 variety trial (1). Percentages of total solids in bulbs of both trials were similar, except for that of Granex 429, which decreased more than $1 \%$. The values for 1986 ranged from $6.84 \%$ for Granex 429 to $8.06 \%$ for Texas Grano 502 (table 2). The bulb samples used in this experiment were classified by size to the nearest 6.4 (1/4 inch) interval. The highest percentage of small bulbs $(25.4-44.5 \mathrm{~mm})$ in diameter corresponded to Granex 429 and Texas Grano 502, with $15.96 \%$ and $12.50 \%$, respectively. Ringer Grano had the highest number of medium size bulbs (50.8-69.9 $\mathrm{mm}$ ): $65.00 \%$. Values of the other cultivars ranged from $40 \%$ to $50 \%$, except for Granex 429 , with only $17.64 \%$ of medium sized bulbs. Granex 429 also showed the highest percentage of large bulbs $(76.2-101.6 \mathrm{~mm})$. There was no significant difference in average bulb weight among cultivars.

After 4 weeks of storage, no significant differences were observed among cultivars in terms of the cumulative percentage of onion bulbs discarded weekly, showing values under $1 \%$ (table 3). After 8 weeks, $7.41 \%$ of the bulbs of Granex 33 had been discarded. This is significantly higher than the corresponding values for other cultivars. No significant differences were measured among other cultivars. The same relation among cultivars held at the end of the 12-week storage period. At this time, $16.14 \%$ of the Granex 33 bulbs had been discarded. Texas Grano 502 followed with $6.16 \%$, a significantly lower value for discarded bulbs.

The damage observed through the 12-week storage period involved bacterial soft rot, caused by the bacteria Emvinia carotovora; black mold rot, caused by the fungus Aspergillus niger; and sprouting (table 4). The highest percentage of bulbs discarded because of bacterial soft rot corresponded to Granex $33(9.36 \%)$. This percentage was significantly higher

TABLE 2.-Total solids, size distribution and average bulb weight of bulb samples evaluated during the 12-week storage period

\begin{tabular}{lccccc}
\hline & & \multicolumn{3}{c}{ Size distribution: } & \\
\cline { 3 - 5 } Cultivar & Total solids & Small & Medium & Large & Average bulb weight \\
\hline & $\%$ & $\%$ & $\%$ & $\%$ & $g$ \\
Granex 429 & 6.84 & 15.96 & 17.64 & 66.39 & $163.42 \mathrm{a}^{2}$ \\
Texas Grano 1025Y & 7.89 & 8.34 & 40.83 & 50.83 & $154.34 \mathrm{a}$ \\
Granex 33 & 7.35 & - & 42.15 & 57.85 & $149.80 \mathrm{a}$ \\
Ringer Grano & 7.86 & 3.36 & 65.00 & 31.66 & $140.73 \mathrm{a}$ \\
Texas Grano 502 & 8.06 & 12.50 & 49.17 & 38.33 & $140.73 \mathrm{a}$ \\
\hline
\end{tabular}

${ }^{1}$ Size distribution by diameter: small $=25.4-44.5 \mathrm{~mm}$; medium $=50.8-69.9 \mathrm{~mm}$; and large $=76.2-101.6 \mathrm{~mm}$.

${ }^{2}$ Values in columns followed by the same letter do not differ statistically $(P=0.05)$ according to Duncan's multple range test. 
TABLE 3.-Cumulative percent of veekly discarded onion trulbs, after 4,8 and 12 weeks of storage

\begin{tabular}{lccc}
\hline & \multicolumn{3}{c}{ Stored bulbs discarded after indicated time interval } \\
\cline { 2 - 4 } Cultivar & 4 weeks & 8 weeks & 12 weeks \\
\hline & $\%$ & $\%$ & $\%$ \\
Granex 33 & $0.93 \mathrm{a}^{\mathrm{a}}$ & $7.41 \mathrm{a}$ & $16.14 \mathrm{a}$ \\
Texas Grano 502 & $0.93 \mathrm{a}$ & $1.85 \mathrm{~b}$ & $6.16 \mathrm{~b}$ \\
Granex 429 & $0.93 \mathrm{a}$ & $0.93 \mathrm{~b}$ & $3.89 \mathrm{~b}$ \\
Texas Grano 1025Y & $0 \mathrm{a}$ & $1.85 \mathrm{~b}$ & $3.13 \mathrm{~b}$ \\
Ringer Grano & $0 \mathrm{a}$ & $0.93 \mathrm{~b}$ & $2.44 \mathrm{~b}$ \\
\hline
\end{tabular}

'Values in columns followed by the same letter do not differ statistically $(P=0.05)$ according to Duncan's multiple range test.

than the values for Texas Grano 1025Y and Ringer Grano, with 2.78\% each. About $8.33 \%$ of the bulbs of Granex 33 were discarded only because of black mold rot. No other cultivars showed this symptom except Texas Grano $1025 \mathrm{Y}$, with just $0.93 \%$ of its bulbs affected. Only Texas Grano 502 showed symptoms of sprouting, with a mean value of $0.93 \%$.

The data obtained during the 12 -week storage revealed that bacterial soft rot was the most damaging condition, followed by black mold rot, whereas sprouting was not an important factor. At the end of 12 weeks, $16.14 \%$ of the bulbs of the deep flat-shaped Granex 33 cultivar had been discarded. This percentage is significantly higher than the corresponding values for the other cultivars, among which there were no significant differences.

\section{LITERATURE CITED}

1. Caraballo, E., G. J. Fornaris, R. Guadalupe and E. Recio de Hernández, 1990. Performance, sizing and total solids of nine onions (Allium cepa) cultivars. J. Agric. Univ. P. R. 74 (1): 1-13.

TABLE 4.-Percent of onion bulbs weekly discarded during the 12-week storage

\begin{tabular}{lccc}
\hline & \multicolumn{3}{c}{ Bulbs disarded because of indicated damage } \\
\cline { 2 - 4 } Cultivar & Bacterial soft rot & Black mold rot $^{2}$ & Sprouting \\
\hline & $9.26 \mathrm{a}^{3}$ & $\%$ & $\%$ \\
Granex 33 & $5.56 \mathrm{ab}$ & $8.33 \mathrm{a}$ & $0 \mathrm{a}$ \\
Texas Grano 502 & $4.63 \mathrm{ab}$ & $0 \mathrm{~b}$ & $0.93 \mathrm{a}$ \\
Granex 429 & $2.78 \mathrm{~b}$ & $0 \mathrm{~b}$ & $0 \mathrm{a}$ \\
Texas Grano 1025Y & $2.78 \mathrm{~b}$ & $0.93 \mathrm{~b}$ & $0 \mathrm{a}$ \\
Ringer Grano & & $0 \mathrm{~b}$ & $0 \mathrm{a}$ \\
\hline
\end{tabular}

'Bacterial soft rot, caused by Erwinia carotovora.

${ }^{2}$ Black mold rot, caused by Aspergillus niger.

${ }^{3}$ Values in columns followed by the same letter do not differ statistically $(P=0.05)$ according to Duncan's multiple range test. 
2. Estación Experimental Agricola, 1979. Conjunto tecnológico para la producción de hortalizas. Univ. P. R., Agric. Exp. Stn., Publ. 102. 2nd ed, p. 25-30.

3. Gierbolini, R. E., 1979. Soil survey of the Ponce area of southern Puerto Rico. USDA, Soil Conservation Serv., in coop. with Univ. P. R., Coll. Agric. Sci.

4. Hardenburg, R. E., A. E. Watada and C. Y. Wang, 1986. The commercial storage of fruits, vegetables, and florist and nursery stocks. USDA Agxic. Handbk. No. 66, p. 63.

5. Hayslip, N. D., D. D. Gull, V. L. Guzmán, J. R. Shumaker and R. M. Sonoda, 1987. Bulb onion production in Florida. Univ. Coop. Ext. Serv., Bul. 238, p. 12.

6. Hurst, W. C., R. L. Shewfelt and G. A. Schuller, 1985. Shelf-life and quality changes in summer storage onions (Allium cepa). J. Food Sci. 50: 761-63.

7. Medrano, H. A., 1989. Hortalizas, p. 118. In: Empresas Agricolas de Puerto Rico. Dep. Agric. Econ. and Sociol., Coll. Agric. Sci., Univ. P. R.

8. Pike, L. M., 1986. Onion breeding; p. 373. In: Bassett, M. J. (Ed). Breeding Vegetable Crops. AVI Publ. Co., Westport, CT.

9. - and P. Leeper, 1982. Five new short day onion varieties for an expanded production season in Texas. Texas A\&M Univ., Agric. Exp. Stn., MP-1514.

10. —, R. S. Horn, P. W. Leeper, M. E. Miller and C. R. Andersen, 1988. "Texas Grano 1025Y": a medium length storage short-day onion. HortScience 23: 635-36.

11. Ryall, A. L., and W. J. Lipton, 1979. Handling, transportation and storage of fruits and vegetables. Vol. 1, Vegetables and Melons, 2nd ed, AVI Publ. Co. Westport, CT, p. 213.

12. Smittle, D. A., 1988. Evaluation of storage methods for "Granex" onions. J. Am. Soc. Hort. Sci. 113: 877-80.

13. Voss, R. E., 1979. Onion varieties and classifications, p. 7-8. In: Onion Production in California. Univ. Calif. Coop. Ext. Serv. Publ. 4097. 